Med. Microbiol. Immunol. 160, 91-97 (1974)

(C) by Springer-Verlag 1974

\title{
Evidence of Precursors of Defective Measles Virus*
}

\author{
Michael P. Kiley and Francis E. Payne \\ Virus Laboratory, Department of Epidemiology, School of Public Health, \\ The University of Michigan, Ann Arbor, Michigan 48104
}

\begin{abstract}
Cytoplasmic extracts of Vero cells infected with wild strain Edmonston measles virus were found to contain at least two distinct nucleocapsid species. The two most prominent species of nucleocapsids sedimented at $200 \mathrm{~S}$ and $110 \mathrm{~S}$ and contained RNA of molecular weight $6.0 \times 10^{6}$ and $0.6 \times 10^{6}$ daltons respectively. Both species of nucleocapsids had a density of $1.31 \mathrm{~g} / \mathrm{cm}^{3}$ in CsCl. A third species sedimenting at $170 \mathrm{~S}$ was not present in all experiments and was not characterized in detail. Infection of cells with undiluted-passage virus usually resulted in production of mostly $110 \mathrm{~S}$ nucleocapsids while both $110 \mathrm{~S}$ and $200 \mathrm{~S}$ species were found when diluted-passage virus was used. These results suggest that measles virus may produce distinct classes of defective virus which contain segments of RNA representing as little as $10 \%$ of the complete viral genome.
\end{abstract}

\section{Introduction}

Isolation of apparent variants of measles virus from brains of pa. tients with subacute sclerosing panencephalitis (SSPE) [13] has given impetus for intensified research effort concerning the biochemistry of measles virus replication. Molecular weights of measles virion peptides $[2,3,16]$ and RNA $[2,15]$ have been determined. The pattern of RNA synthesis in measles infected cells has also been described [7,12]. In addition, we have recently reported on the presence of several distinct size classes of virus specific nucleocapsids in measles virus infected cells [6]. The largest nucleocapsid structure contains the putative complete viral RNA (i.e. 50S) while the smallest structure contains RNA which is approximately one-tenth the size of 50S RNA. The present report deals with further characterization of the intracellular nucleocapsids and factors affecting their synthesis.

\section{Materials and Methods}

Virus. Wild-strain Edmonston virus originally obtained from Dr. H. M. Meyer, Jr., was propagated in BSC-1 cells. Virus stocks referred to as either undiluted. passage or diluted-passage were prepared in Vero cells as follows: Vero cells were infected with BSC-1 cell grown virus either undiluted or at a $\left[10^{-1}\right]$ dilution of virus. When $80 \%$ or more of cells showed cytopathic effects, cultures were frozen and thawed. Infected culture fluids were cleared by centrifugation and stored at $-60^{\circ} \mathrm{C}$.

* Presented at the workshop on molecular and pathogenetic aspects of measles virus, 9./11. April 1974, Belfast, Northern Ireland. 
Cells. Propagation and maintenance of Vero and BSC-1 cells has been described previously [6].

Labeling and Analysis of Infected Cell Extracts. Vero cell monolayers in $250 \mathrm{ml}$ plastic tissue culture flasks (Falcon) were infected at a multiplicity of $0.05 \mathrm{PFU} / \mathrm{cell}$. After a 1 -hr adsorption period, $10 \mathrm{ml}$ of MEM containing $2 \%$ fetal calf serum (FCS) was added to each culture and incubation continued at $37^{\circ} \mathrm{C}$ in $5 \% \mathrm{CO}_{2}$. At $3 \mathrm{~d}$ postinfection, cells were treated with $25 \mu \mathrm{g} / \mathrm{ml}$ of actinomycin D (Calbiochem) and $2 \mathrm{hrs}$ later were exposed to $20 \mu \mathrm{Ci} / \mathrm{ml}$ of $\left[5^{3} \mathrm{H}\right]$ uridine $(28 \mathrm{Ci} / \mathrm{mmole}$, Schwarz/ Mann). Cells were labeled in the continuing presence of actinomycin $D$ and generally harvested after $5 \mathrm{hrs}$ of labeling.

Cells were scraped into $5 \mathrm{ml}$ of ice cold Tris-buffered saline (TBS:0.01 MI Trishydrochloride, $0.14 \mathrm{M} \mathrm{NaCl}, \mathrm{pH} 7.4$ ) and pelleted at $1500 \times$ g. Cytoplasmic extracts were then prepared essentially according to the method of Penman et al. [14]. Pellets were resuspended in ice cold reticulocyte standard buffer (RSB:0.01 M Tris, $0.01 \mathrm{M} \mathrm{NaCl}, 0.0015 \mathrm{M} \mathrm{MgCl}_{2}, \mathrm{pH} \mathrm{7.4)}$ and allowed to swell for $20 \mathrm{~min}$ in an ice bath. Cells were disrupted by 15 strokes of a tight fitting Dounce homogenizer. Nuclei were pelleted at $800 \times \mathrm{g}$ for $10 \mathrm{~min}$. The supernatant fluids, i.e. cytoplasmic extracts, were made $0.5 \%$ with respect to the detergents deoxycholate (Sigma) and BRIJ-58 (Atlas Biochemical Industries) prior to centrifugation. The extracts were then examined by rate zonal centrifugation in $15-40 \%$ (wt/vol) $38-\mathrm{ml}$ sucrose gradients prepared in RSB. Centrifugation was for $3-3.5 \mathrm{hrs}$ at $95000 \times \mathrm{g}$ and $4^{\circ} \mathrm{C}$ in an SW27 rotor. Gradients were fractionated using an ISCO gradient fractionator (ISCO, Lincoln, Nebraska). Equilibrium sedimentation in CsCl of selected sucrose gradient fractions was carried out as described previously [7].

Extraction and Analysis of RNA. Extraction of RNA from sucrose gradient fractions has been described previously [8]. Analysis of this RNA in 5-20\% sucrose gradients prepared in $0.1 \mathrm{M}$ acetate buffer ( $\mathrm{pH}$ 5.0) has also been described [6].

\section{Results}

Characterization of Virus-Specific Nucleocapsids from Measles Infected Cells. Vero cells infected with wild strain measles virus were labeled with $\left[{ }^{3} \mathrm{H}\right]$-uridine in the presence of actinomycin $\mathrm{D}$ at 3 days postinfection and cytoplasmic extracts of infected cells were prepared. After detergent treatment the extracts were analyzed on sucrose gradients and the distribution of radioactivity determined. Fig. 1 shows the presence of two major virus specific labeled structures with sedimentation coefficients of approximately $200 \mathrm{~S}$ and $110 \mathrm{~S}$. The RNA associated with the $200 \mathrm{~S}$ nucleocapsids is nearly $100 \%$ resistant to RNAase and that from the $110 \mathrm{~S}$ structures is also completely resistant when polyribosomes are removed from that region of the gradient by pretreatment with EDTA [6].

Regardless of the size of these nucleocapsids, if they contain the same proportion of RNA to protein, their densities should be identical. The RNA content of measles virus nucleocapsids has been shown to be about $5 \%$ and the density of the nucleocapsids to be $1.30 \mathrm{~g} / \mathrm{cm}^{3}$ in $\mathrm{CsCl}[2,9,17]$. Fig. 2 shows that both the $110 \mathrm{~S}$ and $200 \mathrm{~S}$ nucleocapsids from infected cells have densities of $1.31 \mathrm{~g} / \mathrm{cm}^{3}$ in $\mathrm{CsCl}$ indicating that both species have the same ratio of RNA to protein. This data, along with our previously 


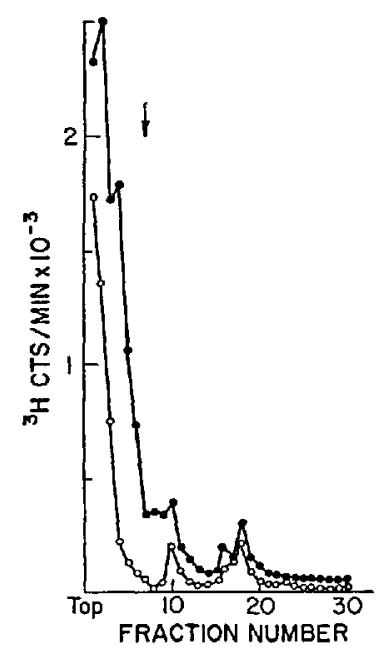

Fig. 1
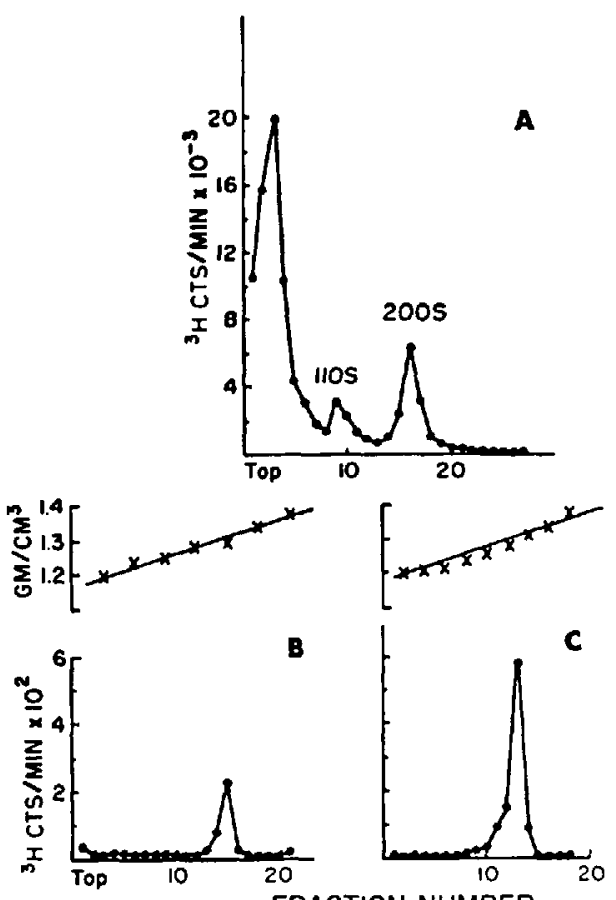

c

Fig. 1. Labeled nucleocapsids from measles infected cells. Infected cells were labeled with $\left[{ }^{3} \mathrm{H}\right]$-uridine for $6 \mathrm{hrs}$ at 3 days postinfection and a cytoplasmic extract prepared. After detergent (deoxycholate and BRIJ-58) treatment, the extract was analyzed on a $15-40 \%$ sucrose gradient in RSB. Fractions were collected and acid insoluble radioactivity determined on aliquots of each fraction before (•after $(0-0)$ ribonuclease treatment. Centrifugation is from left to right and the arrow represents the position of the $80 \mathrm{~S}$ ribosomal monomer in the gradient

Fig. 2A-C. Density of measles specific nucleocapsids. Infected cells were labeled for $12 \mathrm{hrs}$ with $\left[{ }^{3} \mathrm{H}\right]$-uridine at 3 days postinfection and a cytoplasmic extract analyzed on a sucrose gradient containing EDTA (A). Aliquots from the peak fraction of the $110 \mathrm{~S}$ and the $200 \mathrm{~S}$ nucleocapsids from this gradient were then separately mixed with $\mathrm{CsCl}$ and centrifuged to equilibrium. (B) shows the distribution of radioactivity in the $\mathrm{CsCl}$ gradient of $110 \mathrm{~S}$ nucleocapsids and $(\mathrm{C})$ the profile of $200 \mathrm{~S}$ nucleocapsids

reported electron microscopic observations [6] indicate that these structures represent virus-specific nucleocapsids of similar composition but differing in length. The RNA extracted from the $110 \mathrm{~S}$ structure represents about one-tenth the size of the complete genome RNA, $6 \times 10^{6}$ daltons, which is found in the $200 \mathrm{~S}$ nucleocapsid. This is shown in Fig. 3. 


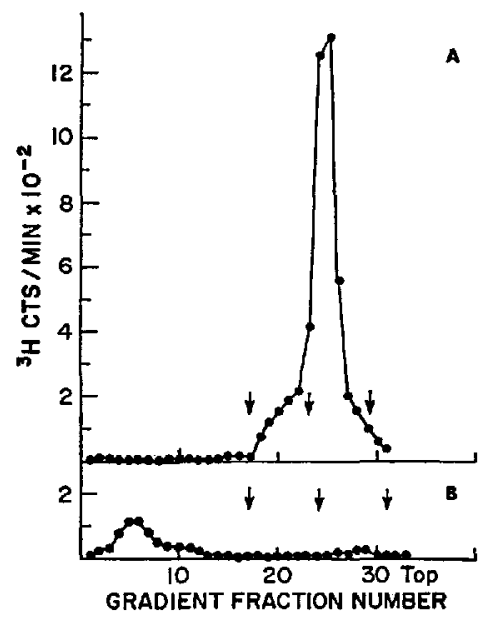

Fig. $3 \mathrm{~A}$ and B. RNA from nucleocapsids. Analysis on $5-20 \%$ sucrose gradients of $\left[{ }^{3} \mathrm{H}\right]$-uridine labeled RNA extracted from (A) $110 \mathrm{~S}$ or (B) $200 \mathrm{~S}$ structures separated in a gradient similar to that depicted in Fig.1. Sedimentation is from right to left and the arrows represent the position in the gradient of $\left[{ }^{14} \mathrm{C}\right]$-labeled cellular ribo-

somal RNA with $\mathrm{S}$ values of 4,18 , and $28 \mathrm{~S}$

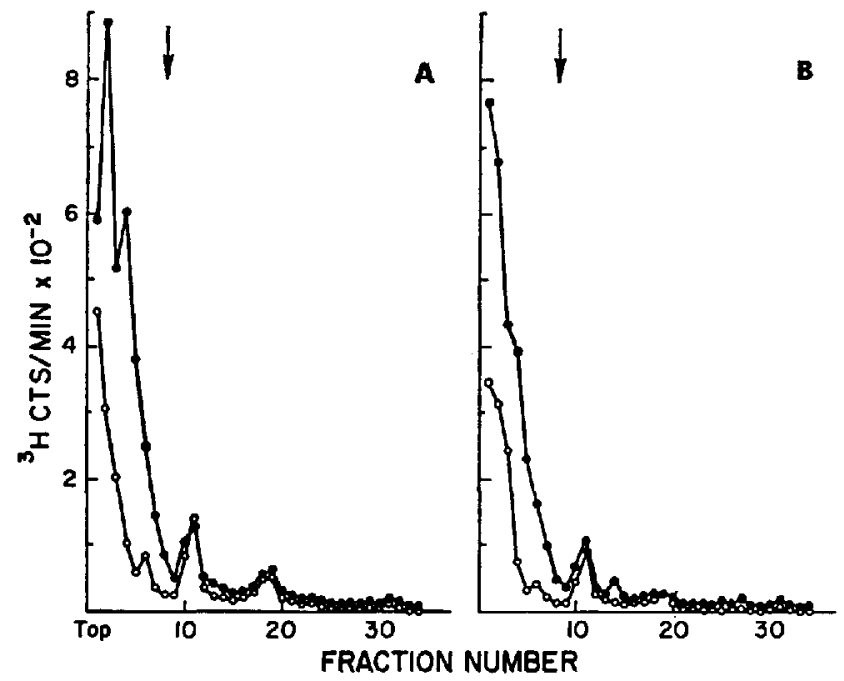

Fig.4A and B. Sucrose gradient analysis of nucleocapsids found in the cytoplasm of infected cells at 3 days following infection with (A) diluted-passage viral stock or (B) undiluted-passage viral stock. Labeling and analysis as described for Fig. 1 
Effect of Passage History on Nucleocapsid Synthesis. Undiluted passage has been shown to lead to the formation of defective interfering particles with several members of negative strand RNA viruses $[5,9]$. We wished to determine the effect of using diluted- or undiluted-passage virus as inoculum on the relative amounts of nucleocapsid species synthesized in infected cells. To this end cells infected with either diluted or undiluted-passage viral stocks were labeled with $\left[{ }^{3} \mathrm{H}\right]$-uridine at 3 days postinfection and cytoplasmic extracts prepared from these cells were analyzed on sucrose gradients containing EDTA. Results of such an experiment are presented in Fig.4 where it can be seen that while both extracts contain $110 \mathrm{~S}$ nucleocapsids, cells infected with diluted-passage virus (Fig. 4A) also contained a relatively large amount of $200 \mathrm{~S}$ nucleocapsids which were not prominent in cells infeeted with undilutedpassage virus (Fig.4B). We have previously shown that $200 \mathrm{~S}$ nucleocapsids were the predominant species in cells infeeted with plaque purified virus, a situation similar to infection with diluted-passage virus [6].

\section{Discussion}

Our results, presented here and elsewhere [6], indicate that measles virus infected cells commonly contain two possibly three distinct nucleocapsid species. The largest of these species sedimented at approximately $200 \mathrm{~S}$ and contained RNA of the size $\left(6 \times 10^{6}\right.$ daltons) found in released infectious virus $[2,15]$. Thus, this species most likely contains the full complement of viral genetic information. A nucleocapsid species sedimenting at $170 \mathrm{~S}$ was not always present and has not been characterized further. A third nucleocapsid species was often detected in infected cells. This structure had a sedimantation coefficient of $110 \mathrm{~S}$ and contained RNA with a molecular weight of $0.6 \times 10^{6}$ daltons. Both $200 \mathrm{~S}$ and $110 \mathrm{~S}$ nucleocapsids have a density of $1.31 \mathrm{~g} / \mathrm{cm}^{3}$ in $\mathrm{CsCl}$ indicating that they have the same ratio of RNA to protein. Electron microscopic examination of the nucleocapsids revealed that they are also structurally similar and that the $200 \mathrm{~S}$ nucleocapsids are approximately ten times the length of the 110S nucleocapsids [6].

Products released from cells infected with diluted and undilutedpassage measles virus were previously found to differ as regards their biological and physicochemical characteristics [1,11]. Relatively small amounts of infectious virus but large amounts of viral antigen were produced by cells infected with undiluted-passage virus. The present results indicate that diluted passage of measles virus results in increased synthesis of $200 \mathrm{~S}$ nucleocapsids relative to $110 \mathrm{~S}$ nucleocapsids in infected cells while the reverse is true when cells are infected with undilutedpassage virus. It has been shown that cells infected with vesicular stomatitis virus contain distinct nucleocapsid species which correspond 
to nucleocapsids present in released infectious virus and defective interfering particles [8]. Defective particle synthesis is favored by passing vesicular stomatitis virus in an undiluted state [5]. By analogy we would predict that the measles virus may produce defective interfering particles containing short nucleocapsids and subgenomic RNA and that their production would be increased by undiluted passage. Hall and Martin (see this volume) now have found that cells infected with undilutedpassage measles virus produce defective virions containing 130 to $150 \mathrm{~S}$ nucleocapsids and 18S RNA which apparently interfere with the replication of infectious virus. It is likely that these nucleocapsids from defective virions are equivalent to the $110 \mathrm{~S}$ nucleocapsids which we find in infected cells.

The possible role of defective interfering particles as modulators of disease, such as SSPE, has been discussed [4]. The role, if any, that synthesis of defective measles virus plays in the pathogenesis of SSPE is currently under investigation in our laboratory.

Acknowledgements. We are indebted to Sandra Geertsen, Karen Findling, Jean Thompson, and Cynthia $\mathrm{D}$. Wardell for excellent technical assistance.

This investigation was supported by Public Health research grant no. NS-09547 from the National Institute for Neurological Disease and Stroke.

\section{References}

1. Chiarini, A., Norrby, E.: Separation and characterization of products of two measles virus variants. Arch. ges. Virusforsch. 29, 205 (1970)

2. Hall, W. W., Martin, S. J.: Purification and characterization of measles virus. J. gen. Virol. 19, 175 (1973)

3. Hall, W. W., Martin, S. J.: The biochemical and biological characteristics of the surface components of measles virus. J. gen. Virol. 22, 363 (1974)

4. Huang, A. S., Baltimore, D.: Defective viral particles and viral disease processes. Nature (Lond.) 226, 325 (1970)

5. Huang, A. S., Wagner, R. R.: Defective $T$ particles of vesicular stomatitis virus. II. Biologic role in homologous interference. Virology 30, 173 (1966)

6. Kiley, M. P., Gray, R. H., Payne, F. E.: Replication of measles virus: distinct species of short nucleocapsids in cytoplasmic extracts of infected cells. J. Virol. 13, 721 (1974)

7. Kiley, M. P., Payne, F. E.: Ribonucleic acid synthesis in cells infected with wild or SSPE strain measles virus. In: R. Barry and B. W. J. Mahy, Eds., Negative strand viruses. New York: Academic Press (in press)

8. Kiley, M. P., Wagner, R. R.: Ribonucleic acid species of intracellular nucleocapsids and released virions of vesicular stomatitis virus. J. Virol. 10, 244 (1972)

9. Magnus, $P$. von: Incomplete forms of influenza virus. Advanc. Virus Res. 2, 59 (1954)

10. Norrby, E. C. J., Hammarskjold, B.: Structural components of measles virus. Microbios 5, 17 (1972)

11. Oddo, F. G., Chiarini, A., Sinatra, A.: On the hemagglutinating and hemolytic activity of measles virus variants. Arch. ges. Virusforsch. 22, 35 (1967) 
12. Parfanovich, M., Hammarskjöld, B., Norrby, E.: Synthesis of virus specific RNA in cells infected with two different variants of measles virus. Arch. ges. Virusforsch. 35, 38 (1971)

13. Payne, F. E., Baublis, J. V.: Decreased reactivity of SSPE strains of measles virus with antibody. J. Infec. Dis. 127, 505 (1973)

14. Penman, S., Scherrer, K., Becker, Y., Darnell, J. E.: Polyribosomes in normal and poliovirus-infected HeLa cells and their relationship to messenger RNA. Proc. nat. Acad. Sci. (Wash.) 49, 654 (1963)

15. Schluederberg, A.: Measles virus RNA. Biochem. biophys. Res. Commun. 42, 1012 (1971)

16. Waters, D. J., Bussell, R. H. : Polypeptide composition of measles and canine distemper viruses. Virology 55,554 (1973)

17. Waters, D. J., Hersh, R. T., Bussell, R. H.: Isolation and characterization of measles nucleocapsid from infected cells. Virology 48, 278 (1972)

\author{
Dr. Michael P. Kiley \\ Virus Laboratory \\ Department of Epidermiology \\ School of Public Health \\ The University of Michigan \\ Ann Arbor, Michigan 48104, U.S.A.
}

